\title{
Ideas in Exile: Refugees from Nazi Germany and the Failure to Transplant Historical Sociology into the United States
}

\author{
George Steinmetz
}

(C) Springer Science + Business Media, LLC 2009

\begin{abstract}
This paper examines the reasons for the variable incidence and differing forms of historical sociology in several different historical periods, with a focus on Germany and the USA. It examines the flows of social scientists between those two countries due to forced exile from Nazi Germany, the American military occupation after 1945, and the voluntary exchange of scholars. The article focuses on extrascientific determinants such as political support for historical scholarship and macrosocial crisis or stability, as well as determinants that are more proximate or internal to the scientific field, such as the ongoing struggle between different epistemologies and the ability of historical sociology to sequester itself into a protected subfield. Historical sociology was one of the two poles of German sociology before 1933, whereas historical sociology had only a handful of proponents in the USA at that time. After 1933, the majority of German historical sociologists went into exile, most of them to the USA. For reasons explored here, the historical orientation of these exiled intellectuals had little resonance in the USA until the 1970s. Rather than being epistemologically "domesticated" in the 1980s, as Calhoun (1996) argued, historical sociology established itself as a subfield that is large enough to produce an internal polarization between an autonomous pole that relates mainly to history and other external allies and a heteronomous pole that mimics the protocols that dominate the sociological discipline as a whole, including a neopositivist epistemology of "covering laws" and at attraction to rational choice theory and quantitative methods, or qualitative simulacra of multivariate statistical analysis. In Germany, historical sociology failed to survive the Nazi period. Several leading Weimar-era historical sociologists stayed in Germany after 1933 but were unable to reestablish their prominence either because of their Nazi collaboration or because their work was dismissed by a new generation trained during the Nazi period for presentist, policy-oriented, "American-style", or else trained in the USA after the war. The handful of exiled historical sociologists who returned to Germany after 1945 were marginalized, stopped working historically, or moved into other disciplines like Political Science. The explanation of these trends has to be multicausal and conjunctural. The influx of historical sociologists to the USA from Germany was unable to produce a historicization of the discipline until 1970s, when positivist hegemony was challenged for other reasons.
\end{abstract}

\footnotetext{
G. Steinmetz $(\bowtie)$

Department of Sociology, University of Michigan, Ann Arbor, MI, USA

e-mail: geostein@umich.edu
} 
The crisis of Fordism undermined the social regularities that had made positivist "constant conjunctions" seem plausible and at the same time rendered historicist ontologies more plausible. The neo-Marxist historical sociology gave rise to a neo-institutionalist countertrend, which was itself eventually countered by a culturalist and conjuncturalist turn (Adams et al. 2005). In Germany, however, the society-wide destabilization of Fordism did not lead to a historicization of sociology. The extinguishing of the Weimar-era historical school in sociology meant that only high theory and "American-style" empirical social research remained as vital options. As a result, the crisis of Fordism and the ensuing social discontinuities and complexities did not give rise to historical sociology but were felt mainly within theory (e.g., the "risk society" theory of Ulrich Beck).

Keywords Refugees $\cdot$ Sociologists $\cdot$ Nazism $\cdot$ Historical sociology

\begin{abstract}
"Refugees are the sharpest dialectical thinkers. They are refugees as a result of changes and their sole object of study is change."

—Bertolt Brecht, "Refugee Conversations" (1940, p. 264)

"As [the exile] settles elsewhere, all those loyalties, expectations, and aspirations that comprise so large a part of his being are automatically cut off from their roots. His life history is disrupted, his 'natural' self relegated to the background of his mind .... Since the self he was continues to smolder beneath the person he is about to become, his identity is bound to be in a state of flux .... Where then does he live? In the near vacuum of extra-territoriality .... the exile's true mode of existence is that of a stranger."

- Siegfried Kracauer, History: The Last Things before the Last (1995, pp. 83-84)

"Intellectual transportation needs carriers, and ... I was one of them."

—Paul Lazarsfeld (1969, p. 271)
\end{abstract}

\title{
Introduction
}

Historical sensibilities and epistemologies have had a hard time establishing themselves in American sociology. Before 1914, most sociologists proposed evolutionary models of social change that ignored alternative developmental paths or treated deviations from a standard developmental pattern as anomalies. A few American sociologists rejected ahistorical approaches during the interwar years (Barnes and Becker 1938; Steinmetz 2007a). The "dogma of rigid sequence in social evolution" was rejected by Howard P. Becker (1934, p. 22), for example. But US sociology became unreceptive to historical thinking after 1945 and remained so for at least three decades (Steinmetz 2005a, b). There was a brief opening in the 1970s, which saw the creation of a working group for historical sociology and, at the end of the decade, a new section in the American Sociological Association (ASA). ${ }^{1}$ But as Craig Calhoun - the first elected chairperson of the Comparative-Historical section, 1984-1986-

\footnotetext{
${ }^{1}$ On the early historical section see the memo entitled "Committee on Sociological History. A Committee of Social Scientists and Historians," April 9, 1980, which lists Cahnman as one of four "Former Chairmen." Werner Cahnman papers, Leo Baeck Institute. Folder 2/55 (“General-Chronological,” 1913-1980).
} 
has argued, historical sociology was "domesticated" in the 1980s as part of a more general reconsolidation of a "mainstream" in the US sociological field (Calhoun 1996, 2007). Only in recent years have sociologists started to explore more historical alternatives to nineteenth century evolutionary thinking and twentieth century scientism (Adams et al. 2005).

The paradox, however, is that American sociology was offered incomparably rich resources for reimagining their discipline along historical lines after 1933, with the influx of three dozen German refugee social scientists imbued with neohistoricist epistemologies. Historical sociology, as Raymond Aron (1935) observed at the time, was one of the two poles of German sociology during the Weimar Republic. At a congress of German university sociologists in 1932 Karl Mannheim argued that the "historical-individualizing" approach was the leading style of sociology in Germany at the time (Mannheim 1932a, pp. 9-14). Mannheim acknowledged that sociology had "originally developed after the pattern of the generalizing natural sciences" in Germany as elsewhere, ignoring "the specifically historical dimension of its subject matter." But during the 1920s, he continued, German sociology had come to be "increasingly dominated by the principle of historicism." This involved treating every social reality as what Rickert had called a "historical individual", that is, as the unique product of a historically contingent cluster of causal mechanisms and series (Mannheim 1952 [1924], pp. 84, 86). Mannheim argued that German "Wissenssoziologie" (sociology of science) had made science itself an object of historical study, having "discovered that science ... is embedded in the stream of social and historical reality" (Mannheim 1932b, p. 281).

There were at least 40 historical sociologists in the Weimar Republic (see Table 1). Historical sociologists like Reinhart Bendix and Lewis Coser who emigrated before completing a doctoral degree are not included here. Nor does this table include any historical sociologists who received their university degree in Germany during or after the Nazi period, such as Jürgen Habermas and Günther Roth. Information from Strauss and Röder (1983), Wittebur (1991), and other sources available from the author. This was more than half of all full-time or part-time sociology professors in Germany. All but a handful of the scholars listed in Table 1 were driven into exile after 1933 (Wittebur 1991; Kruse 2001, p. 107). Most of them ended up in the USA, with a few notable exceptions like Norbert Elias and Karl Mannheim, who went to England, Siegfried Landshut (Palestine), and Alexander Rüstow (Turkey). Many of the émigrés continued to advocate a historicized version of sociology, but their message fell largely on deaf ears in the USA. Some of them, including Werner Cahnman, Paul Honigsheim, Hans Gerth, and Albert Salomon, eventually attracted at least some attention for their views in American sociology. Others, like Ernst Manheim and Hans Speier, moved into less historical forms of sociological practice. A number of historical social scientists who had been part of sociological field while they were still in Germany were channeled into other disciplines in the USA (for example, Franz Neumann, Arthur Salz, Wolfram Eberhard, Karl Wittfogel, Adolph Lowe, and Eugen Rosenstock). But while some groups of German refugees may have succeeded in transferring "an entire scientific culture to the United States" (Krohn 2000, p. 40), this was not true of the sociologists. American sociology was generally unreceptive to the émigré historical sociologists' message and did not develop a significant historical subfield until the end of the 1970s.

A few historically oriented sociologists, including Arnold Bergsträsser, Emerich Francis, and Gottfried Salomon-Delatour, returned to Germany after 1945. Others reemerged from "inner emigration". But they failed to reestablish historical sociology as a significant part of the discipline in Germany. Sociological research in Nazi Germany had been mainly oriented toward the present, above all the immediate needs of the regime (Klingemann 1996). After 
Table 1 Historical sociologists in the Weimar Republic and their trajectories.

Bergsträsser, Arnold (Germany $\rightarrow$ USA $\rightarrow$ Germany; 1896-1964) ${ }^{\mathrm{a}}$

Brinkmann, Carl (1885-1954)

Cahnman, Werner (Germany $\rightarrow$ USA; 1902-1980) ${ }^{a}$

Eberhard, Wolfram (Germany $\rightarrow$ China $\rightarrow$ Germany $\rightarrow$ Turkey $\rightarrow$ USA; 1909-1989) ${ }^{\text {a }}$

Elias, Norbert (Germany $\rightarrow$ Paris $\rightarrow$ England $\rightarrow$ Germany; 1897-1990) ${ }^{\text {a }}$

Francis (Franzis), Emerich (Germany $\rightarrow$ Austria $\rightarrow$ England $\rightarrow$ Canada $\rightarrow$ USA $\rightarrow$ Germany; 1906-1994) ${ }^{\mathrm{a}}$

Freyer, Hans (1887-1969)

Gerth, Hans (Germany $\rightarrow$ London $\rightarrow$ USA; 1908-1978) ${ }^{\mathrm{a}}$

Grünfeld, Ernst (1883-1938)

Heberle, Rudolf (Germany $\rightarrow$ USA, 1896-1991)

Heimann, Eduard (Germany $\rightarrow$ USA, 1889-1967) ${ }^{a}$

Honigsheim, Paul (Germany $\rightarrow$ Paris $\rightarrow$ Panama $\rightarrow$ USA, 1885-1963) ${ }^{\text {a }}$

Kantorowicz, Hermann (Germany $\rightarrow$ USA $\rightarrow$ England; 1877-1940) ${ }^{a}$

Kracauer, Siegfried (Germany $\rightarrow$ Paris $\rightarrow$ USA; 1889-1966) ${ }^{a}$

Landshut, Siegfried (Germany $\rightarrow$ Palestine $\rightarrow$ Germany; 1897-1968) ${ }^{\mathrm{a}}$

Löwe (Lowe), Adolf (Adolph) (Germany $\rightarrow$ England $\rightarrow$ USA; 1893-1968) ${ }^{\text {a }}$

Manheim, Ernst (Germany $\rightarrow$ London $\rightarrow$ USA; 1900-2002) ${ }^{\mathrm{a}}$

Mannheim, Karl (Germany $\rightarrow$ England; 1893-1947) ${ }^{a}$

Martin, Alfred von (1882-1979) ${ }^{\mathrm{b}}$

Mayer, Carl (Germany $\rightarrow$ USA; 1902-1974) ${ }^{\mathrm{a}}$

Meyer, Julie (Germany $\rightarrow$ USA; 1897-1970) ${ }^{a}$

Müller-Armack, Alfred (1901-1978)

Mühlmann, Wilhelm Emil (1904-1988)

Neumann, Franz (Germany $\rightarrow$ Great Britain $\rightarrow$ USA; 1900-1954) ${ }^{a}$

Oppenheimer, Franz (Germany $\rightarrow$ Palestine $\rightarrow$ USA; 1864-1943) ${ }^{\mathrm{a}}$

Pappenheim, Fritz $\left(\right.$ Germany $\rightarrow$ Spain $\rightarrow$ France $\rightarrow$ USA; 1902-1964) ${ }^{\text {a }}$

Plessner, Helmuth (Germany $\rightarrow$ The Netherlands $\rightarrow$ Germany; 1892-1985) ${ }^{\text {a }}$

Rosenstock-Huessy, Eugen (Germany $\rightarrow$ USA; 1888-1873) ${ }^{\mathrm{a}}$

Rubinstein, Nina (Germany $\rightarrow$ France $\rightarrow$ USA; 1908-1996) ${ }^{\mathrm{a}}$

Rüstow, Alexander (Germany $\rightarrow$ Turkey $\rightarrow$ Germany; 1885-1963) ${ }^{\mathrm{a}}$

Salomon, Albert (Germany $\rightarrow$ Switzerland $\rightarrow$ USA; 1891-1966) ${ }^{\text {a }}$

Salomon-Delatour, Gottfried (Germany $\rightarrow$ France $\rightarrow$ USA $\rightarrow$ Germany; 1892-1964) ${ }^{\mathrm{a}}$

Salz, Arthur (Germany $\rightarrow$ Great Britain $\rightarrow$ USA; 1881-1963) ${ }^{\mathrm{a}}$

Scheler, Max (1874-1928)

Schelting, Alexander von (Germany $\rightarrow$ USA $\rightarrow$ Switzerland; 1894-1963) ${ }^{\text {a }}$

Speier, Hans (Germany $\rightarrow$ USA; 1905-1990) ${ }^{a}$

Tillich, Paul (Germany $\rightarrow$ USA; 1886-1965) ${ }^{\mathrm{a}}$

Weber, Max (1864-1920)

Weber, Alfred (1868-1958) ${ }^{\mathrm{b}}$

Wittfogel, Karl (Germany $\rightarrow$ England $\rightarrow$ USA; 1896-1988) ${ }^{\mathrm{a}}$

Location of exile and later countries of residence; dates of birth and death are in parentheses

${ }^{\text {a }}$ Refugee after 1933

${ }^{\mathrm{b}}$ Remained in Germany: inner emigration, job loss, or voluntary demission 
1945, many of the Nazi sociologists were able to remain in academic positions. The leaders of postwar West German sociology were unreceptive and even hostile to any revival of Weimar sociological neohistoricism, describing it as an immature and unscientific version of the philosophy of history (Kruse 1999a, b, 2001). Historical research was also avoided by some because it would have called attention to the Nazi past. As a result, historical sociology nowadays "does not exist" in Germany (Bock 1994, p. 184)—with a few notable exceptions, including a rich vein of historical research on the history of sociology. Unlike the ASA, the German Sociological Association (GSA) does not have a special section for historical sociology. "Historical sociology" or "historische Soziologie" has become largely synonymous in Germany with work carried out in the English-speaking world according to “Anglo-Saxon" traditions (Spohn 1996).

This somewhat simplified narrative presents a series of puzzles. Why was sociology more oriented toward history in Germany than in the USA before 1933? What explains the failure of the refugee historical sociologists to transfer their program to American sociology? Why did historical sociology emerge after the 1970 s as a recognized subfield in American sociology, four decades after the influx of historical sociologists? Were there any connections between the two moments, and if so, what were they? What explains the failure of historical sociology to reestablish itself in Germany since 1945? Most generally, what factors reinforce and undermine historical approaches among sociologists?

There has been a growing interest in the transnational circulation of ideas and intellectuals (Heilbron et al. 2008), including refugee intellectuals (Coser 1984; Krohn 1993 [1987]). Paired with this is an interest in tracking and explaining variations in epistemological and methodological orientations and preferences among disciplines (Steinmetz 2005c; Lamont 2009), national and political contexts (Wagner et al. 1999; Barth et al. 2005; Schweber 2006; Heilbron 2008; Fourcade 2009), and historical periods (Steinmetz 2007a; Calhoun and VanAntwerpen 2007). A third interest is transdisciplinarity (Steinmetz 2007c), and a fourth is the sociological history or historical sociology of sociology (Calhoun 2007). The present article brings together all of these foci insofar as the scholars in question circulated transnationally as refugees among different political systems, switched disciplines or worked in interdisciplinary spaces, and lived through the massive reconfiguration of American and German social science marked by World War II and Nazism (Herman 1996; Klingemann 1996; Szöllösi-Janze 2001).

\section{Historical Sociology as Contested Terrain}

In order to define "historical sociology", we need to keep in mind that this definition is one of the disputed issues and stakes of competition in the field or subfield itself. Much nineteenth century, presociological theory was historical in the restricted sense of specifying universal patterns of macrohistorical development. By the 1920s, however, such evolutionary approaches had been discredited by the experience of Europe's "rebarbarization" in World War I and by sociologists' growing appreciation of historicist epistemologies such as the Southwest German school of neo-Kantian philosophy (Dilthey, Windelband, Rickert, Lask) that was so important for Max Weber (Oakes 1987). Historical sociology during the interwar period was usually inspired by some form of historicism and took for granted that every social object or event was historically produced and had to be grasped as a "historical individual", that is, as a unique constellation that could not be explained by general laws or dissolved into transhistorical categories (Kruse 2001, p. 106). A leading historical sociologist from the Weimar period who defended what he called 
Geschichtssoziologie ("History-Sociology") was Alfred Weber, Max Weber's younger brother (A. Weber 1921, 1927, 1931, 1935; von Borch 1955). Alfred Weber (1931, p. 285) rejected what he called the "old historical sociology" - a category that for him included Hegel, Comte, Marx, St. Simon, and Spencer-for its evolutionary and progressivist orientation, insisting that "the possibility of such a sociology is nowadays largely rejected". According to Alfred Weber, one cannot understand or explain the meaning or motor of history in general, universal terms, but can only examine "different types of development" and "concrete configurations of historical change" (Gugolz 1984, p. 46). Another proponent of Geschichtssoziologie, Hans Freyer, rejected the idea of laws of social change in favor of a view of history as a radically unpredictable open-ended process (Freyer 1933, 1954). According to Alfred Weber, any historical event had to be analyzed as the contingent "result of the conjunctural effects of an ... often unconnected complex of separate causal facts" (A. Weber 1931, p. 288). Weber and Freyer, along with the majority of Weimar-era sociologists, insisted on the distinction between the natural and cultural sciences or Geisteswissenschaften and saw sociology as belonging to the latter one (Freyer 1926). This implied that sociology necessarily had an interpretive dimension. Alfred Weber therefore described his approach not just as historical sociology but also as a form of cultural sociology (Kultursoziologie).

This definition still does not solve the question of what counts as historical sociology. If Weimar sociology was polarized between historical and "formal" sociology (associated above all with Leopold von Wiese), historical sociology inside the ASA nowadays takes the form of a subfield in a Bourdieusian sense. Like the enveloping sociological field, this subfield is characterized by competition for subfield-specific stakes (although a characteristic feature of a subfield is that the latter one may not be distinct enough to generate its own forms of symbolic capital and habitus). Like any field, a subfield is typically characterized by two axes: One is defined by the volume of subfield-specific symbolic capital; the second is defined by the degree of autonomy from external forces. All of the subfield's members also participate in the environing field and have to pass through the same gate-keeping procedures as all of its members. But the subfield may revise or invert the values placed on different sorts of activities in the broader field. ${ }^{2}$ Scholars located at the autonomous pole of the subfield often seek allies outside the field, while scholars located at the heteronomous pole mimic the values of the environing field. In the subfield of historical sociology, this means that autonomous scholars connect with historians, philosophers, and others outside the sociology field, while heteronomous scholars interact mainly with other sociologists and with the kinds of extradisciplinary allies preferred in the wider field. At the subfield's heteronomous pole historical sociology is approached along the lines of neopositivist epistemology, with an orientation toward general laws (Kiser and Hechter 1991), ${ }^{3}$ comparison as a qualitative proxy for the experimental method used in the natural sciences (Sewell 1996; Steinmetz 2004), and rejection of interpretive methods as unscientific (Mahoney and Rueschemeyer 2003). At the subfield's autonomous pole, there

\footnotetext{
${ }^{2}$ In the subfield of political theory within American political science, for example, the prevailing views of "value-freedom" and normativity and of the hierarchy of empirical and theoretical work are directly opposite the dominant views of the same matters within the discipline as a whole. The creation of a subfield may protect a rare plant like poetry, political theory, or historical sociology, but it may also immunize the rest of the field against the subfield's heterodox messages (Mihic et al. 2005).

${ }^{3}$ Kiser and Hechter's (1991) call for general laws echoes a widely read treatment of American sociology from the 1950s which argues that "at no time during the development of sociology has the existence of a system of fundamental, natural laws which govern the behavior of men been seriously questioned" (Hinkle and Hinke 1954, p. 9).
} 
is a widespread acceptance of neohistoricist or critical realist positions, both of which argue that historical events need to be interpreted culturally and explained as the products of changing and unpredictable constellations of determinants. ${ }^{4}$

The preceding discussion suggests that the boundaries of Weimar historical sociology should be defined with reference to a core group of founding historical sociologists' recognition of others as historical sociologists. I also look for broad textual agreement with the typical Weimar neohistoricist sociological orientation: an emphasis on the conjunctural overdetermined production of individual events and on the cultural interpretation of social practice. A few historical sociologists continued to argue for uniform patterns of social evolution.

In order to be a historical sociologist, one had to be a sociologist. This points us to a broader question, concerning the inclusion in and exclusion from that nascent academic discipline.

\section{The Field of Sociology}

One approach to this boundary question would limit the population of sociologists to people employed as sociologists in universities and research centers. But this would make it impossible to include the founders of the German Sociological Association, all of whom came from disciplines other than sociology (Karger 1978, p. 142). The first university chairs in sociology were created in the 1920 s, and their numbers increased very slowly (von Ferber 1956, p. 198). Max Weber was the name most frequently mentioned at the meetings of the German Sociological Association before 1933, but Weber was an economist and historian who only described himself as a sociologist in the last years of his life (M. Weber 1946; Kaesler 1984, p. 36). Although a handful of chairs in German universities included "Soziologie" in their title by the end of the Weimar Republic (Kaesler 1984, pp. 626-628), most of the recognized sociologists had chairs in other disciplines, or titles that combined sociology with some other academic discipline.

At a minimum, the category of "sociologist" should include anyone participating in the founding of the academic discipline by contributing to early sociological congresses, founding sociological associations, and editing journals dedicated to "sociology". The field obviously should also include anyone with an academic appointment as a sociologist or in a sociology department. In the USA, this latter criterion would encompass lecturers and professors at the assistant, associate, and full levels. In Weimar Germany, this category included people employed as an ordinary (ordentlicher), extraordinary (außerordentlicher), or honorary professor (Honorarprofessor), as lecturer (Privatdozenten), or as an emeritus professor (Emeriti could continue to teach in the German system; Köttgen 1933). We should also include Assistenten, who assisted professors in research and teaching while writing a doctoral dissertation or Habilitation thesis. Assistants were used in ever greater numbers over the course of the Weimar Republic due to the financial crisis. These positions were "not infrequently the launch pads for academic careers" (Grüttner and Kinas 2007, p. 130). The case of Norbert Elias, who did not "set his feet on the first secure rung of the academic career ladder" until he was 57 years old (Mennell 1992, p. 21), underscores the need for a more inclusive definition of professional status.

\footnotetext{
${ }^{4}$ Other differences include themes or topics of investigation, use of archival materials, insistence on comparison as a guarantor of scientificity, and acceptance of the nation state as a natural unit of analysis. See Steinmetz (1999); Adams et al. (2005)
} 
We also need to include sociologists in nontraditional schools in our German sample. These schools included the technical, commercial, labor union, women's, and "people's" colleges (Frauenhochschulen and Volkshochhschulen) as well as the deutsche Hochschule für Politik in Berlin, founded in 1920 as a center for political sociology and political science (Bleek 2001). The director of the Cologne Volkshochschule from 1922 until 1933 was the Weberian historical sociologist Paul Honigsheim (Röhrig 1987, p. 103). Julie Meyer (later Meyer-Frank) earned her Dr. rer. pol. at Erlangen University in 1922 with a historicalsociological dissertation on the origins of the Nuremburg patriciate (Meyer 1928) and became a lecturer at the Nuremberg Frauen- und Volkshochschule. Meyer-Frank immigrated to the USA in 1937 and taught sociology at the New School. The importance of including nontraditional schools is underscored by the Frankfurt Akademie der Arbeit (Academy of Labor), which was cofounded in 1921 by the historical sociologist Eugen Rosenstock (Faulenbach 1982) and which had at least two other historical sociologists teaching there: Carl Mayer and Arthur Salz. Mayer completed a doctoral thesis in 1929 under the direction of Alfred Weber and Karl Jaspers on the historical sociology of religion and taught at the Frankfurt Academy until the Nazis closed it down on April 1, 1933 (Gugolz 1984, p. 58; Grathoff 1974). Mayer then emigrated and taught for the rest of his career at the New School, returning only occasionally to teach in Europe. Arthur Salz studied with Georg Simmel and was a friend and colleague of Max Weber's and an associate during the 1920s of the Heidelberg Institute for the Sciences of Society and the State (InSoSta) which was headed by Alfred Weber (Blomert 1999).

Disciplines are dynamic fields, not collections of static positions. Their boundaries are continually being constructed, reinforced, and redrawn by institutional mechanisms such as the requirement of specific diplomas and by numerous informal processes by which insiders grant recognition to some outsiders as members of their field while refusing to grant that recognition to others. In other words, we need to count as sociologists not just those with formal positions in the discipline but anyone who is recognized as a sociologist by the group that controls such processes of definition. Operationally, this means starting with the field-founders and working forward in time. Sociology had started to cohere as an academic disciplinary field in Germany before 1914, as demonstrated by the existence of a core group of seven people at the first two meetings of the GSA: Max and Alfred Weber, Leopold von Wiese, Werner Sombart, Georg Simmel, Franz Oppenheimer, and Ferdinand Tönnies (Kaesler 1984, pp. 37-38). Membership in the GSA was by invitation only, even after 1945. Max Weber and Sombart were founding editors of one of the two leading German sociology journals before 1933, the Archiv für Sozialwissenschaft und Sozialpolitik, and Alfred Weber became an editor after WWI. The second leading sociology journal, Kölner Vierteljahrshefte für Soziologie, was edited by von Wiese. The GSA's founders therefore had an enormous and lasting impact on subsequent membership patterns and on the contours of the scientific field. ${ }^{5}$

\footnotetext{
${ }^{5}$ The GSA stopped operations between 1934 and 1946. Sociology lost almost all autonomy during the Nazi era; the entire sociological discipline was distrusted as repressed as left-leaning and heavily Jewish (but see footnote 14). Most of the sociologists who continued working in Nazi Germany oriented themselves toward official policy agendas, published in Nazi journals, and subordinated their discipline to "interdisciplinary" projects. For example, the ethnosociologists Richard Thurnwald and Wilhelm Mühlmann increasingly aligned their scientific agendas and conceptual vocabulary with Nazi ideology in the late 1930s, designing policies of compulsory assimilation, forced labor, and national socialist colonial rule (Steinmetz forthcoming).
} 
In addition to holding a sociology position or belonging to the GSA, other signs of participation in the field of German sociology include publishing in the above-named journals and writing, editing, or contributing to sociological treatises, textbooks, encyclopedias, and series. None of these individual markers should, however, be taken as conclusive evidence of membership in the field. Each individual who was not a member of the GSA has to be assessed on a case-by-case basis. For example, I include Arthur Salz as a German sociologist before 1933 even though he stopped interacting with sociologists after coming to the USA in 1934 and is unknown among sociologists today. But Salz participated in the GSA's precursor organization, the Verein für Sozialpolitik, and in the early meetings of the GSA (Kaesler 1984, p. 61) and was a friend of the Webers. I include Nina Rubinstein because her doctoral dissertation on the French aristocracy's political emigration after 1789 was accepted by Karl Mannheim at Frankfurt University in 1933. Rubinstein was forced to emigrate before she could defend the thesis and received her Ph.D. only in 1989 (Raith 1999; Rubinstein 2000), but she was clearly part of the sociological field before 1933. I do not include refugees who began their sociology studies only after reaching the USA, even if they eventually became historical sociologists. This means that Lewis Coser and Reinhard Bendix are excluded from the list of Weimar historical sociologists. Coser left Germany before beginning his studies and enrolled as a graduate student in sociology at Columbia University in the 1950s, earning his Ph.D. at the age of 41 (Rule 2003, p. 93). Bendix only began his studies after arriving in the USA in 1938, entering the University of Chicago as a freshman that year and earning his MA degree in sociology 5 years later with a thesis on the rise of German sociology (Bendix 1943).

Siegfried Kracauer presents an illuminating borderline case of membership in the Weimar sociological field. Kracauer "went largely unnoticed in sociological circles" and was "never really accepted in the scholarly world" of Weimar Germany (Frisby 1986, p. 161). He was not invited to become a member of the GSA and was never mentioned at their meetings before 1933 (Kaesler 1984, pp. 610-611), even though he had studied with Simmel and published on Simmel and other sociological topics (Kracauer 1922, 1998 [1930]). It would therefore be anachronistic to include Kracauer in the pre-1933 sociological field. But he is arguably present in the postwar German sociology field. He was included in a German sociology lexicon in 1959, which noted that his works "had not been sufficiently explored by German sociology until now" (Mierendorff 1959, p. 280). Kracauer's work started to be reviewed and cited in German sociology journals. In 1952, he conducted sociological research for Lazarsfeld's Bureau of Applied Social Research (Jay 1975-1976, p. 74; Witte 1987; Kracauer 1952-1953). One of Adorno's students planned a dissertation on Kracauer as a sociologist (Jay 1975-1976, p. 86, note 144). Nowadays, Kracauer is included in sociological encyclopedias and collections (e.g., Kaesler and Vogt 2000, pp. 230-233).

American and German sociology differed in size and epistemological orientation, and both of these attributes mattered enormously for the experience of the refugee sociologists. Sociology had consolidated earlier as a university discipline and expanded more rapidly in the USA. There were already 55 full-time and 372 part-time professors in sociology in the USA in 1909 and about a thousand by the mid-1920s (Bernard 1909, p. 186; Walther 1927, p. 1). By the end of the Weimar Republic, there were around 50 full-time or part-time sociology professors and 140 sociologists in Germany (Kaesler 1984, pp. 626-628; Lepsius 1983; Wittebur 1991; Fleck 2007, p. 188). The two countries continued to diverge after 1945. By the 1970s, there were about 630 sociology Ph.D.'s being produced each year in the USA - as many as existed in the entire Federal Republic of Germany (Hardin, 1977, p. 39). By 2001, there were 4,903 full-time sociology faculties in the USA, almost half of 
them in programs granting Ph.D.'s. ${ }^{6}$ In Germany, there were about 260 full and associate professors in 1972, and this number seems to have declined somewhat since then (Lüschen 1994, p. 18; Siefer and Abrahams 1994, p. 285). ${ }^{7}$ The professional organizations also differ in size. The GSA started in 1909 with 39 members and grew to 207 in 1956, 760 in 1980, 1,300 in 1997, and 1,600 in 2007 (Glatzer 1994, p. 227). Membership in the American Sociological Association grew from 115 founding members in 1905 to over 1,000 in 1920, 7,500 in 1963, and 14,000 in 2005 (Murphy 2005). Due to this difference in the size of the two fields, the handful of émigré historical sociologists represented a much smaller force in the American field than in Weimar Germany.

The two fields also differed dramatically in their openness to historical sensibilities. Many of the founders of US sociology came from economics and natural science fields, and historical approaches had a much weaker presence than in Germany. A telling example of the desire to differentiate sociology from history in the initial period is Albion Small, founder of Chicago's sociology department. Small had studied history and historical economics at Berlin and Leipzig from 1879 to 1881 . His own work was not historical, however, but was oriented instead toward discovering the "typical" meaning of practice in "typical" situations (Small 1905). Robert Park and Ernest Burgess (1924, p. 11) began their Introduction to the Science of Sociology (1924) by locating sociology on the side of the natural sciences. If sociology was concerned at all with history, they argued that it was with the parts of history from which it was possible to "arrive at natural laws and generalizations in regard to human nature and society, irrespective of time and place" (ibid., p. 11). Similar statements can be found in the writings of nearly all of the American sociologists of the founding generations, with rare exceptions like Charles Cooley (Steinmetz 2007a) and Harry Barnes. Many factors influenced US universities' differing willingness to take in refugee historical sociologists, including the financial crisis of the Great Depression and xenophobia and anti-Semitism within the universities (Lamberti 2006). But we should not overlook the fact that most American sociologists were uninterested in or even openly opposed to the Germans' more humanistic style of sociology.

\section{Intellectual Assimilation and Intellectual Transfer}

Additional barriers to the transfer of German historical sociology are related to the fact that social scientists are themselves historical beings. Shifts in intellectual style are especially likely in the case of refugees, who "become irrevocably distanced and dis-located from their originating milieu, losing a place in their native field of honor without securing one in their new setting" (Bourdieu and Wacquant 2000, p. 176); they acquire the "double consciousness" discussed as the mark of the emigrant by Abdelmalek Sayad (1999). It is almost impossible for scholars to move smoothly from one national academic field to another. The question of the "failure of theoretical transference" (Sutherland 1974) thus needs to be reformulated. We need to ask not just about the ability of a collective intellectual formation to achieve transfer but also about the degree of continuity or rupture in individual intellectual trajectories. More specifically, we need to distinguish between sociologists who become less historical after

\footnotetext{
${ }^{6}$ Survey of Baccalaureate and Graduate Programs in Sociology, 2000-2001, conducted by the American Sociological Association.

${ }^{7}$ See "DGS - Gesamterhebung, Soziologie an deutschen Hochschulen", at http://www.soziologie.de/.
} 
emigrating (or returning to Germany) and those who become more historical. There is no single unitary form of intellectual or scholarly exile, but a plurality of positions.

A variety of different possible strategies are available to the émigré, although it is obviously not entirely or mainly a question of choice. They can try to convert their existing forms of symbolic capital and habitus to fit the new fields. They may strike an intermediate strategy by matching their existing strengths to existing fields. The exile may try to recreate the native field, to become a nomothete of a new nomos (Bourdieu 2000, p. 51), which she can then dominate. At an extreme described by Kracauer and Edward Said as the typical position of the exile, the immigrant may isolate himself from his new environment: "you draw lines around you and your compatriots" (Said 2000, p. 178). Kracauer (1995 [1969], pp. 83-84) claimed that the stance of the isolated "stranger" was the "true mode of existence" of every exile (see epigraph to this essay).

The first strategy, intellectual conversion or assimilation, is illustrated by Ernst Manheim (Karl Mannheim's cousin, who spelled his last name differently). Manheim's 1933 book on the eighteenth and nineteenth century public sphere anticipated Habermas' famous study by a half century (Manheim 1979; Averbeck 2005). Once he arrived in the USA, however, Manheim's work became almost entirely focused on the American present (Averbeck 1999; Smith 2005). Hans Speier also assimilated his sociological work to the new context. Speier had passed his doctoral examination under Karl Mannheim on the topic of Lassalle's philosophy of history. His dissertation, written under Karl Jaspers, was on the young Hegelians (Speier 1989, pp. 6-7). Speier's book on the German white-collar workers, which he completed in 1933 (but published only in 1977), began from the puzzle of the disjuncture in Weimar Germany between salaried employees' proletarianized economic condition and their nonproletarian status consciousness. Like much Weimar-era sociology, this book reconstructed the present moment historically, tracing the ways in which whitecollar workers' efforts to reclaim their eroded social esteem relied on definitions of social status from the nineteenth century (Speier 1986, pp. 80-82). Speier initially taught at the New School but then worked for various wartime agencies beginning in 1942. When he returned to the New School in 1947, where historical Weberianism was the dominant stance among the other sociologists (see Salomon 1935; Mayer 1935), it seemed to him to have become "almost provincial", a "strange oasis of exile" (Speier 1986, p. 21). Speier established a social science division at the Rand Corporation, where he stayed until 1969.

The intermediate strategy is represented by Paul Lazarsfeld, a self-described "European "positivist"' (Lazarsfeld 1969, p. 271). Lazarsfeld's scientific position originated in the Austrian homeland of logical positivism. Although American sociological positivism was less philosophically sophisticated than the Austrian version and more obsessed with quantification, Lazarsfeld was able to find numerous American allies who joined him in promoting a presentist, policy-oriented, statistical form of sociology (Pollak 1979; Gemelli 2000), and to "finance a whole school of followers, which indigenized the Vienna tradition of social research on U.S. soil" (Etzkorn 1987, p. 59). He also became a favored intermediary for American social science foundations in Europe. The differences between the "Vienna tradition" and the American version disappeared as soon as one moved beyond Lazarsfeld to his collaborators and followers (Abbott 2005).

Speier's comment about the "University in Exile" as a "strange oasis" points to the strategy in which the exile "compensates for disorienting loss by creating a new world to rule", a world "that somewhat resembles an old one left behind forever" (Said 2000, p. 181). The émigré may react to his new environment by insisting more vigorously on his original intellectual stance. This might involve efforts to create converts or to find allies. 
This approach is illustrated by the discussions around "fact and value, science and politics" among the members of the exile community at the New School after the war, which seemed to some students "fresh and provocative, particularly when contrasted to the increasingly technical and specialized preoccupations of most other American graduate schools" (Rutkoff and Scott 1986, p. 197). It is illustrated by people like Hans Gerth, Carl Mayer, Paul Honigsheim, Albert Salomon, and Alexander von Schelting, who sought a US audience for the "authentic" thought of Max Weber as against the "de-historicized" Weber they saw as being promoted by Talcott Parsons (Cahnman 1960, p. 120). ${ }^{8}$ The career of émigré sociologist Werner Cahnman provides an example of stubborn resistance to intellectual assimilation. Cahnman was classified as a sociologist for the first time when he was hired as a visiting professor at the University of Chicago in 1940 (Maier and Waxman 1983, p. 6). He became an outspoken advocate of historical sociology, publishing historical articles on the city (Comhaire and Cahnman 1962; Cahnman 1966); colonialism and racialism (Cahnman 1943); and German Jewry (Cahnman 1989) and an edited collection on history and sociology (Cahnman and Boskoff 1964). Cahnman was "an important 'activist" in a "movement" for the "revitalization of historical sociology" aimed at "overcoming the historical provincialisms still so prevalent in many graduate training programs" in sociology (Holzner 1965, pp. 579580; Cahnmann 1978). In the 1970s, he helped coordinate a group of historical sociologists in the New York City region. ${ }^{9}$ Arguably, Cahnman is the forgotten founder of the historical sociology section of the ASA, even though his interpretivist and historicist version of Weber was defeated in the first election of officers of that section by a camp associated opposed to Weberian interpretivism and historicism. ${ }^{10}$

The émigré who resists adaption risks isolation. The stance of self-encapsulation is exemplified by the Frankfurt Institute for Social Research in exile, especially by Adorno and Horkheimer, even if they were not as fully isolated in the USA as sometimes suggested (Bahr 2007, ch. 2). Adorno (1968, pp. 338-339) encouraged this view, writing that "by nature and personal history, I was unsuited for 'adjustment' in intellectual matters". Some of the historical sociologists contributed to their own isolation. Paul Honigsheim spent most of his life in the USA after 1938, but his writing appeared in German or in "obscure editions with a limited readership" (Etzkorn 1987, p. 61; Silbermann and Röhrig 1987, pp. 177-204). Honigsheim advised only one or two doctoral dissertations during his entire career there (Etzkorn 1987, p. 59). Honigsheim cannot really be said to have chosen isolation, however, since he was unwillingly isolated during the years (1938-1960) he spent at Michigan State University, formerly an agricultural school. Hans Gerth was also isolated (N. Gerth 2002), even though Wisconsin was already a leading department by that time. But the postwar Wisconsin department was increasingly dominated by neopositivist scientism and by research on the present-day USA (Sewell 2005; Steinmetz 2007a). Gerth's isolation resonated with and reinforced that of his famous student and collaborator $\mathrm{C}$.

\footnotetext{
${ }^{8}$ Von Schelting published his Habilitation thesis as Max Webers Wissenschaftslehre (Max Weber's Theory of Science) in 1934 and worked on the translation of the first part of Weber's Wirtschaft und Gesellschaft with Edward Shils, Talcott Parsons, and A.M. Henderson, which appeared in 1947 as The Theory of Social and Economic Organization.

${ }^{9}$ W. Cahnman papers, Leo Baeck Institute, New York City.

${ }^{10}$ According to the recollections of Craig Calhoun, Theda Skocpol talked him into running for secretary of the comparative-historical section in 1981 against a candidate associated with the interpretivist, neohistoricist Weberian camp (Stephen Kalberg). Calhoun recalls that opposition was also motivated by a perception of the Cahnman group as hostile to Marxism. (Personal communication to the author from Craig Calhoun).
} 
Wright Mills. ${ }^{11}$ Cahnman seems to have been less isolated than Honigsheim and Gerth, even though he spent many years teaching at two black universities (Fisk and Atlanta universities) and later at Rutgers. This suggests that other mechanisms were at work besides institutional location. Rather than examining individual-level determinants of strategy and status, however, I want to emphasize that there was very little interest among American sociologists in the historical kinds of sociology being offered by the German refugees.

A further analytic complication stems from the fact that some of the émigrés returned to Germany permanently or taught there occasionally after 1945 . We need to ask how exile affected the returnees' stance toward the interrupted project of Weimar-era historical sociology and how sociologists who had stayed in Germany or those who came of age after Nazism reacted to these returnees and to the program they embodied.

\section{Historical Sociology in Germany: the Disappearing Act}

Why was historical sociology more widespread in Germany before 1933 than in other countries? We can point first to some nationally-specifically intellectual sources. German sociology emerged from a broader intellectual constellation that was already polarized between historicist and "nomothetic" positions, the latter one modeled on the natural sciences. Corresponding to this division, Weimar sociology was split between "historical" and "systematic" approaches, while there was no real analog to German historicism in the USA. The pervasiveness of this intellectual configuration is revealed by similar divisions in other Weimar-era academic fields like ethnology (Frobenius and the Kulturkreis school versus Thurnwald and the functionalists), legal studies (Carl Schmitt versus the legal positivists), and history (as seen in the conflict over Karl Lamprecht's historical positivism). The division between Heidegger and the neo-Kantians in Weimar philosophy not only has some of the same characteristics but also reveals the marginalization of scientistic positions in Germany: Almost all scholars were arguing in ways that would have located them at a nonpositivist extreme corner of American social science discussions at the time. ${ }^{12}$

Another distinctive feature of German sociology between 1900 and 1933 was its pattern of recruitment from other disciplines. The two primary pools were economics and philosophy, both disciplines conducive to historical thinking. The historical school of German economics, represented within sociology by Max Weber, Alfred Weber, Werner Sombart, Franz Oppenheimer, and others, differed from its British, Austrian, and American counterparts in emphasizing the historical "individuality" of economic facts. Two strands of German philosophy shaped Weimar historical sociology. Hegelianism and its Marxist successors emphasized historicity (Freyer 1930), while neo-Kantian phenomenology opposed construing the social sciences as natural sciences (Kracauer 1922; Scheler 1926). The “decisionism" associated with Carl Schmitt, Troeltsch (1924), and Freyer (1931, 1933)

\footnotetext{
${ }^{11}$ For a wonderful treatment of this fraught relationship between these two isolated men, see the forthcoming biography of Mills by John H. Summers, who presented a paper at the Eastern sociological association meetings in Baltimore on March 20, 2009. Gerth left behind some 2,000 pages of unpublished manuscripts (Bensman et al. 1982, p. xi).

${ }^{12}$ For example, the notion of the Geisteswissenschaften as distinct from the natural sciences, anathema to American social science positivists, was developed by the neo-Kantian Wilhelm Windelband. Heidegger staked out an even less positivist position, one that was hostile to the very idea of a social science. As Bourdieu notes, in Heidegger, 'there is a hatred of statistics (harping on the theme of the 'average') seen as a symbol of all the operations of 'levelling down' which threaten the person (here called Dasein) and its most precious attributes, its 'originality' and 'privacy”" (Bourdieu 1991, p. 79).
} 
worked against any view of history as progressive and law-driven, emphasizing instead "the emergent 'event' which determines its environment rather than being produced by it" (Lazarsfeld 1969, pp. 143-144).

One might anticipate that history would be a major source of recruitment for historical sociologists. Weimar sociology welcomed historians such as Alfred von Martin, Ernst Grünfeld, Carl Brinkmann, and Andreas Walther. Von Martin wrote a habilitation thesis in history in 1915 and taught history at Frankfurt (1921-1924) and Munich (1924 to 1931) before moving to Göttingen as Professor and Director of the Sociological seminar, when he published Soziologie der Renaissance in 1932. Ernst Grünfeld came to sociology after writing a habilitation thesis on historical economics and colonial politics (Hagemann and Krohn 1999, p. 206) and publishing on the history of European imperialism in East Asia (Grünfeld 1913). Grünfeld committed suicide at a desperate moment during his "internal exile" in 1938, after completing a path breaking analysis of the sociology of exile or "social perpherialization" (Grünfeld 1939). Brinkmann, a student of Gustav Schmoller, published a critical study of imperialism in 1921 and a book on English history in 1936, but also conducted research after 1933 that was "closely related to the reorganization plans of the Nazi regime for Western Europe as well as for the newly conquered Eastern territories" (Klingemann 1992, p. 133).

Although von Martin and Grünfeld brought a historical sensibility into sociology, Andreas Walther illustrates a different trajectory wherein sociologists with backgrounds outside the discipline overidentify with the perceived mainstream as a compensation for their anomalous origins. Walther published several archivally based medieval histories before becoming ordentlicher Professor of sociology at Hamburg University in 1927. He soon turned into a missionary for quantitative, presentist, American-style sociology, which he defended against charges of "crass positivism" (Walther 1927). In 1928, Walther rejected Siegfried Landshut's first habilitation thesis on the grounds that the author was an "antisociologist" who "wanted to make sociology regress into a historical discipline" (Wassner 1986, p. 396). Landshut had criticized sociological tendencies toward "the quantification and calculation of results, the positing of rules and laws, and the demotion of reality to "mere raw material for abstractions"”, arguing that there was "no need for a special boundary between the sociological and the historical problematic" (Nicolaysen 1997, p. 106; Landshut 1929, p. 34). As a Jew and a Marxist, Landshut was compelled to emigrate in 1933. Walther was clearly more than a simple opportunist; however, the "American" position he adopted was extremely unpopular among German sociologists before 1933. Ironically, the American style of sociology gained status in Nazi Germany. Walther became a Nazi party member in March 1933, and only then did he become more prominent in the discipline, supervising 33 dissertations in Hamburg after 1933 (Wassner 1985, p. 51). ${ }^{13}$ Walther's paradoxical relationship to his own background as a historian is a warning against any simple interpretation of the effects of openness of disciplinary recruitment.

German sociologists' view of history as open-ended and unpredictable was probably reinforced by the massive ongoing social crisis of the Weimar Republic and did not simply reflect neohistoricist philosophy and the so-called crisis of science. The extraordinary contingency of sociopolitical life was difficult for anyone to overlook as the fate of the German economy and democracy hovered in the balance, to be decided upon by the

\footnotetext{
${ }^{13}$ See the comments by Peter Coulmas in Klingemann (1988), however, which suggest that Walther did not completely abandon his historical orientation during the Nazi period.
} 
seemingly aleatory decisions of voters and parliamentarians and their unpredictable, combined effects (Ermakoff 2008). By contrast, the postwar period in West Germany, at least after 1950, was characterized by a comparative stability that encouraged spontaneous sociologies of the social as a quasinatural object whose repetitive movements could be captured by general laws (Schelsky 1961; Bock 1994; Steinmetz 2005b).

External resources and political pressures also shape the balance of power within sociology. During the 1920s, left-wing and liberal German politicians supported the establishment of sociology as a field, seeing it as more democratic than older disciplines like history. It was also thought that sociology could provide students with a "synthetic orientation toward society". The liberal Prussian Minister of Education and Cultural Affairs Carl H. Becker urged the human sciences to conduct "research on the present" that was "simultaneously historical and sociological" (1925, p. 39). Becker supported the appointment at Leipzig of Hans Freyer, a friend from the German youth movement (Muller 1987, p. 133; Üner 1994, p.7). The government of the state of Saxony tried to force the right-wing professoriat at Leipzig to appoint Marxist and Jewish faculty (Muller 1987, pp. 136-143). Another important external influence during the interwar period and the early Nazi years was the Rockefeller foundation, which supported research projects and institutions and provided fellowships for German sociologists to visit the USA (Krohn 2000; Fleck 2007). After 1933, the political system worked in the opposite direction, evicting liberal, left-wing, and Jewish professors from the German universities and putting massive pressure on academics to conform to the regime's ideology (even if academic fields retained some degree of autonomy from the state).

Taking a longer historical view, the central puzzle is the complete disappearance of Weimar historical sociology, although none of the sociologists in Table 1 was murdered by the Nazi state. Of the 38 historical sociologists in Germany active in 1933, 31 went into exile and three into "inner emigration" (Ernst Grünfeld, Alfred von Martin, and Alfred Weber). ${ }^{14}$ Among the four others who stayed in Germany, Brinkmann became a founding member of the SS and a member of the Nazi University Instructors' League (Klingemann 1986, p. 137; Remy 2002, p. 41); Freyer (1931) welcomed the "revolution from the right" and served the Nazi state in various ways, although he never became a party member; Mühlmann and Müller-Armack both joined the Nazi party.

But historical sociology was unable to establish itself in the USA or to regain its earlier centrality in postwar West Germany despite the efforts of Weber, Freyer, von Martin, and re-emigrants like Salomon-Delatour. By the mid-1950s, the main "schools" in (western) German sociology were formal ahistorical theory, whose figurehead was Leopold von Wiese, and empirical quantitative research on contemporary problems, which was concentrated at Münster and Cologne Universities and at the Sozialforschungstelle Dortmund (Dortmund Center for Social Research) (Weyer 1984; Schelsky 1959, ch. 3). Frankfurt School critical theory emerged as a third dominated pole, but Horkheimer and Adorno were ambivalent about historical sociology and Weimar intellectual legacies and were committed to promoting a more modern "Americanized" version of sociology, at least until the end of the 1950s. Their impact was also limited by the vigorous anti-Marxism of the period. By the end of the 1950s, historical sociology seemed to have disappeared

\footnotetext{
${ }^{14}$ About half of the historical sociologists listed in Table 1 were Jewish. This does not mean, however, that historical sociology was associated mainly with Jewish sociologists. Some leading figures such as Werner Cahnman, Norbert Elias, Siegfried Landshut, Karl Mannheim, Albert Salomon, and Franz Oppenheimer were Jewish, but Max and Alfred Weber, Hans Freyer, Hans Gerth, Carl Mayer, Hans Speier, and Paul Honigsheim were not.
} 
altogether in Germany, or to have migrated into other disciplines such as political science and (somewhat later) social history (Steinert 1990, p. 32). Most of the Nazi-era quantitative sociologists were able to keep teaching after 1945 or to move into research institutes, despite their collaboration with the murderous regime (Klingemann 1996). A new generation of quantitative sociologists born between 1926 and 1930 received training in the USA and felt themselves to be "young Turks" (Scheuch 1990, p. 42). Some of the leading disciplinary "modernizers" claimed to be wedded to "logical empiricism" or "logical positivism" (Stendenbach 1964, p. 9; Albert 1956). Their goal was to replace the old-fashioned traditions of "German sociology" with a more "internationalized" (that is, Americanized) sociology "in the Federal Republic of Germany" (Scheuch 1990), one that was "nothing but sociology" (nichts als Soziologie) — that is, one that rejected theory and speculative philosophy (König 1958, p. 7).

After 1945, many who had been historical sociologists before 1933 moved into disciplines other than sociology or returned too late to influence the postwar configuration:

- Horkheimer and Adorno, the most influential returnees, both had joint positions in Sociology and Philosophy at Frankfurt. But they stopped working on recognizably historical topics, and in the early 1950s, Adorno joined in the ongoing critique of Weimar historical sociology as a form of speculative philosophy (Adorno 1972).

- Von Schelting re-emigrated to Switzerland and wrote books on Russian history, but had little influence on German sociology. Similarly, Landshut moved back to Hamburg, where he helped to establish the new department of Political Science (Nicolaysen 1997, ch. 8), removing him from the field of sociology. Bergsträsser moved into political science and became increasingly interested in the "third world". Along with his ambiguous relationship to the Nazis, this explains Bergstraesser's low visibility in postwar German sociology.

- Heimann, Lowe, and Gerth returned to Germany only in retirement. Cahnman was invited twice to Munich as guest professor and received emeritus status there in 1968, but he did not move back to Germany permanently.

- Salomon-Delatour returned to teach at Frankfurt in 1958. During the 1920s, SalomonDelatour had defined sociology as "the interpretation of historical processes", and in the early 1960s, he was still criticizing ahistorical forms of sociology (Stölting 1984, p. 55; Salomon 1922; Oppenheimer 1964, p. 350). By the time he reestablished himself in Frankfurt, there were no allies left (Henning 2006, pp. 50-51, note 8).

- Alfred von Martin had resigned his post at Göttingen when the Nazis came to power, but he stayed in Germany. He resumed teaching at Munich University in 1946 and continued to publish historical work (von Martin 1948, 1951), but his work had little impact on a discipline now fixated on the present.

- The post for a sociology professor at Munich that had been created in 1955 for von Martin was offered in 1958 to Emerich Francis (Franzis). Francis returned from the USA, where he had been teaching sociology at Notre Dame. Much of his work before 1933 had been historical, including his first book on the philosopher priest Bernard Bolzano and the "Geistesgeschichte of eastern Central Europe" (Franzis 1933). In 1951, Francis had argued that history and sociology were closely related (Francis 1951). After his return to Germany, however, he treated historical questions only cursorily, even in his pioneering work on nationalism (Francis 1965).

- Wilhelm Mühlmann's work before the war represented a mix of sociology, ethnology, and history. His doctoral dissertation was a historical ethnology of ancient precolonial Tahiti (Mühlmann 1932). During the Nazi era, Mühlmann joined the party and shifted 
his ethnological focus from the "primitive Naturvölker" to eastern Europe and Eurasia, with an eye toward Nazi land occupation politics and the assimilation (Umvolkung) of eastern "German" populations. After the war, Mühlmann was blocked from academic employment until 1957, when he obtained a post at Mainz. In 1960, he was recruited at Heidelberg, where he directed the new "institute for sociology and ethnology" that trained some of the most interesting postwar German ethnographers. Mühlmann was forced out of his job at the end of the 1960s by student protests (Michel 1992; Sigrist and Kößler 1985). The missing discipline in his postwar teaching and research was history.

- Hans Freyer had been called the leading proponent of a "historical sociology" that differed from the "social evolutionism once so popular" by Barnes and Becker (1938, p. 921). But Freyer lost his professorship at Leipzig after the war due to his cooperation with the Nazis. He continued to write in the vein of Weimar-era historical sociology (Freyer 1954) and was able to lecture for 3 years at Münster, from 1953 to 1955, but he was no longer a central player in sociology (Muller 1987; Schäfer 1990).

- Alfred Weber, finally, is best known nowadays for his early work in economic location theory. As noted above, however, he was the leading proponent of historical sociology in the Weimar period. As a left-liberal and anti-Nazi, he was forced into retirement after 1933. His Kulturgeschichte als Kultursoziologie was published in the Netherlands in 1935. In 1945, at the age of 78 , he emerged from retirement and initially became influential at Heidelberg. Weber joined a commission to deNazify Heidelberg University and had a burst of new historical publications. But he was declared a nonsociologist by his former student Talcott Parsons, now at the height of his influence, and was called a philosopher of history by René König, the rising star of West German sociology.

Why was historical sociology not renewed in postwar Germany? Why did those sociologists who continued to work on historical topics and in a neohistoricist spirit lose all of their influence or drift toward less historical approaches? In part, historical research was avoided because it would have led sociologists to examine their discipline's close involvement with Nazism. German sociology had reoriented itself toward presentist policy research during the Nazi era. Rather than turning this research into material for historical investigation, however, serious research on Nazi-era sociology did not begin until the 1980s. At the first postwar meeting of the German Sociological Association in 1946, the president of the association Leopold von Wiese insisted that sociology needed to free itself from "speculative historical philosophy" - a codeword for historical sociology. Von Wiese proceeded to describe the Nazi era as a "pest" that had "descended on the people, who were unprepared for it, from the outside, like a sneak attack." Nazism was a "metaphysical secret that sociology may not touch" (von Wiese 1948, p. 29). Indeed, it had become almost impossible to examine any period in the German past without touching on Nazism, since the dominant "exceptionalist" historiographic framework interpreted everything since the Reformation as a step toward the Final Solution (Steinmetz 1997). Moreover, von Wiese himself had done "all kinds of regime-conforming work" right up to the end of 1944, when Cologne University was closed (Derks 2001, p. 498).

Another opponent of Weimar style historical sociology was Helmut Schelsky (1959), who held a series of key positions in postwar German sociology and academia. Schelsky had joined the SA in 1932 and the Nazi Studentenbund in 1933; in 1938, he joined the Nazi party. In 1941, Schelsky became the assistant to Hans Freyer, who was then heading the German Scientific Institute in Budapest. Schelsky helped Freyer put together dossiers on 
the "racial" origins and political views of Hungarian professors (Muller 1987, p. 313; Schäfer 1990, p. 155). Schelsky (1959, p. 37) argued that by 1933, Weimar sociology "selbst am Ende war" - that it had reached a stage of terminal decrepitude. This overlooked the fact that most of the sociologists had been actively repressed, rather than reaching a natural end. Schelsky (1959, p. 136; 1961, pp. 463-465) argued that modern "scientific civilization" had created the possibility for a positivist, objectivist, value-free, and quantitative social science by "stabilizing the basic structures of industrial civilization".

While some avoided historical research because they feared that it would lead to serious investigation of Nazism and Nazi sociology, others suggested that historical sociology was itself somehow suspect. In the widely read Fischer-Lexikon Soziologie, René König assimilated Alfred Weber to "historical and social philosophers" like Spengler, who were linked to Nazism. The "development of sociology as a science", König wrote, required that it distance itself from work like Weber's (König 1958, p. 151). In essays that went into the book The Destruction of Reason, Georg Lukács (1981) linked the "German sociological tradition" to Nazism.

The end of German historical sociology was also hastened by a cluster of factors we can summarize as Americanization. After 1945, American occupation officials and foundations helped remake German sociology. Different groups of German sociologists competed for the allegiance of sociologists working for the US military government, including Nels Anderson, author of The Hobo (1923). Anderson organized and coordinated a "Middletown"-style community survey of Darmstadt financed by the US military government. The Darmstadt Study provided several dozen budding German social scientists with experience in empirical social survey methods (Weyer 1984, pp. 323-328; Gerhardt 2007, pp. 232238; Anderson 1956). The agents of the US occupation and officers from the Ford and Rockefeller foundations promoted certain German sociologists and sociological styles and disadvantaged others.

A final reason for the decline of historical sociology was the stabilization of socioeconomic turbulence, codified in Konrad Adenauer's phrase "no experiments" and analyzed subsequently as Atlantic Fordism. The macroeconomic modulation of cyclical turbulence and the welfare state's buffering of the impact of unemployment and other misfortunes lent surface plausibility to positivist models of the social as a regularized predictable machine (Steinmetz 2007b).

\section{The USA: Historical Sociology as a Well-Structured Subfield}

There was some interest in historical topics and epistemologies among American sociologists before 1914, but this largely disappeared after WWI. The piecemeal emergence of historical sensibilities in American sociology was due partly to German influences. The earliest native-born American historical sociologists had studied in Germany or were linked to members of the exile group. Howard P. Becker had studied with Scheler and Honigsheim in Cologne in 1926-1927 and had written a Chicago sociology dissertation on secularization in ancient Greek cities (Becker 1930). Becker criticized sociologists' "crippling neglect" of history. Like the German historical sociologists, he rejected the "dogma of rigid sequence in social evolution" and universal and teleological philosophies of history (Becker 1934, pp. 20, 22). Barnes and Becker (1938, p. 760) wrote that the "sociologist should not approach his data with the intention of forcing them, willy-nilly, into a Procrustean bed of 'timeless' categories that are a priori generalizable." Preferable, they argued, were Weberian ideal types firmly rooted in "the granite of history" and 
"constructed through knowledge of the non-comparable ... particularities of human behavior in those epochs", while remaining "transportable between certain points of the historical terrain" (Barnes and Becker 1938, p. 763). The main sources for their rejection of evolutionism and ahistorical concepts were Max and Alfred Weber, Heinrich Rickert, and Hans Freyer (Barnes and Becker 1938, p. p. 777). Barnes and Becker concluded that "American historical sociology is just beginning to get under way" and that "it has every prospect of a brilliant future" (ibid., p. 790). Becker and Barnes were among the lone advocates of historical sociology prior to the influx of German sociologists (Maus 1962, pp. 158-159).

C. Wright Mills was an early advocate of historical sociology who was connected to a German refugee, Hans Gerth, who had written a dissertation under Karl Mannheim on "the social historical situation of the bourgeois intelligentsia at the turn of the 18th century" (Gerth 1976). Gerth consistently criticized the ahistoricism of US sociology (Gerth 1959). In The Sociological Imagination, Mills argued that "all sociology worth of the name is "historical sociology" and that "the social sciences are themselves historical disciplines" (Mills 1959, p. 146). Showing his debt to German neohistoricism and to Gerth in particular, Mills argued that "any given society is to be understood in terms of the specific period in which it exists" (ibid.). There is, Mills continued, "no 'law' stated by any social scientist that is trans-historical. ... The only meaning of 'social laws' or even of 'social regularities' is such 'principia media' as we may discover, or if you wish, construct, for a social structure within an historically specific era. We do not know any universal principles of historical change; the mechanisms of change we do know vary with the social structure we are examining" (ibid., pp. 149-150).

Other pioneers of historical sociology were connected to German scholarship and German refugees. Barrington Moore, Jr., a founder of postwar American historical sociology, worked as a policy analyst for the Office of Strategic Studies during World War II with Franz Neumann and Herbert Marcuse. Historical sociologists Reinhart Bendix and Lewis Coser were themselves refugees from Nazi Germany. Sociologist Günther Roth, who emigrated to the USA in 1953, published an important early historical study of the German social democrats in imperial Germany (Roth 1963) and a number of additional books on Max Weber. It is thus at least partly accurate to say that present-day American or "Anglo-American" historical sociology has roots "in the German cultural sphere" (Kruse 1999a, p. 192). But the influence of the refugee historical sociologists was far from direct or immediate.

Starting in the mid-1970s, larger numbers of US-based sociologists began working historically ways, writing dissertations on historical topics, and paying attention to historians' concepts, problematics, and vocabulary (Steinmetz 2005a). During the 1980s, there was an attempt to reconfigure historical sociology along the lines of a qualitative positivism, modeling historical explanation on multiple regression analysis. Starting in the second half of the $1980 \mathrm{~s}$, sociology departments began hiring historical sociologists. Comparative historical sociology now became a fairly well-structured subfield within the field of sociology, large enough to sustain a section of the ASA up to the present.

\section{Toward an Explanation}

In explaining the variable presence and strength of historical sociology over time and across national settings, there seem to be five causal factors internal to sociology and academia and two that are external. It is unclear, however, whether any of these mechanism is a 
necessary condition. Some of them are completely unique to a given historical situation, such as the alleged role of Nazism.

The first and most obvious internal factor is has to do with intellectual traditions, specifically the presence or absence of ideas supportive of a historical sociology. Weimar Germany's inherited intellectual culture presented sociology with an unimaginably rich set of reflections on historicity and the human sciences. American sociology before 1933 generally lacked these resources; post-1933 sociology profited greatly from the influx of these same currents, even if it did not take advantage of them until much later, if at all.

A second factor, one that I have not been able to examine here, is Marxist culture. Marxism was a crucial intellectual precondition for historical sociology in Weimar Germany and again in the USA during the 1970s. Marxism can play both a promoting role with respect to historical sociology, contributing to historical ways of thinking, and a suppressing role to the extent that Marxism takes a reductionist, static, and transhistorically generalizing (see for example the critique by von Below 1926; for a contemporary example of an evolutionary version of Marxism, see Cohen 2001).

The third internal factor relates to the structure of the field of sociology. Sociology has been unusually open to newcomers and outsiders. Where this leads to the recruitment of historians or historically minded scholars from other disciplines, such openness may contribute to historical sociology. Even here, however, we saw that historians may overcompensate or overidentify with the supposedly more scientific pole of sociology.

Fourth, where there is a well-defined subfield, as in contemporary American sociology, historical sociology may be better protected from the pressures of the field as a whole. The existence of a heteronomous pole of the historical sociology subfield which emulates the dominant research protocols and epistemologies of the discipline may paradoxically shield the subfield's autonomous pole from epistemological policing, allowing its members to engage in cross-disciplinary and transdisciplinary "travelling" and communication with external fields (Steinmetz 2007c).

A fifth factor that has sometimes been conducive to historical sociology is the existence of institutions dedicated to interdisciplinarity or transdisciplinarity, such as the Frankfurt Institute for Social Research (Wiggershaus 1994), the Heidelberg InSoSta (Blomert 1999), the Leipzig Institute for Cultural and Universal History before 1933 (Diesener 1993), the New School for Social Research (Rutkoff and Scott 1986), and the École des Hautes Études en Sciences Sociales (Revel and Wachtel 1996).

Two external mechanisms also influenced the fate of historical sociology. State officials during the Weimar period sometimes promoted historical sociology, while American occupation forces and US foundations after 1945 tended to back nonhistorical forms of sociology. Historians of American social science have argued that the Rockefeller foundation and federal funding agencies promoted present-oriented problem-solving research packaged in positivist and usually quantitative formats (Ross 1991), even if this was less true of their priorities in postwar German political science (Plé 2001, pp. 206-207).

A final external factor refers to macrohistorical constellations. Highly stabilized socioeconomic conditions, like the "thirty glorious years" of postwar Fordism, may erode the spontaneous plausibility of historical modes of thinking for sociologists and other social actors. By contrast, sociohistorical crises often encourage more historical modes of thinking as they reveal the fragility, contingency, and mutability of social arrangements. Of course extrascientific events cannot lead directly to scientific ideas, which usually have some autonomy from the temporal powers and general trends. Moreover, society-wide crises may erode the relative autonomy of fields as research is mobilized for political goals or 
defunded. They may also shape the intellectual contexts of academic fields. Crises confer greater spontaneous plausibility on historical ways of viewing the social, and this may filter indirectly into the fields of sociology and other social and human science disciplines. Hans Freyer (1930, p. 106) and Karl Mannheim (1932a) suggested that sociology itself emerged as a response to society-wide crisis. It may be no coincidence that the two great eras of the efflorescence of historical sociology, namely the 1920s in Germany and the 1970s in the USA, were periods of intense generalized crisis and great uncertainly about the future. This was felt immediately among academics through intensified competition for a limited number of jobs. Fields other than sociology saw a rise in historical approaches during the same period. Literary criticism, for example, turned away from the New Criticism and the ahistorical text-bound version of deconstruction that prevailed in the USA gave way to the "new historicism", which led literary scholars into the historical archives. As socioeconomic conditions for academics became more stabilized in the 1990s, the new historicism declined as a leading paradigm.

Does this mean that those who favor historical sociology should hope for crisis? Should they expect that a macrosocial crisis will strengthen the historical orientation of social scientists? Hoping for crisis would certainly be a mistake and not for ethical and political reasons alone. I have tried to identify some of the causal mechanisms responsible for two remarkable waves of historical sociology and for one remarkable decline thereof. Crisis and its converse, social stabilization, have appeared as important mechanisms in each of these cases. But we should also recall that the 1930s in the USA was also a period of intense crisis but one that did not lead to a wave of historicism in sociology. Nor was there a significant increase in historical sociology in West Germany during the prolonged crisis of the 1970s and 1980s. Historical explanation is not the same thing as historical prediction. Social forecasting is impossible, except for very short-term projections into the immediate future. If there is one valid generalization about sociohistorical life is that historical events are complexly overdetermined by an ever-shifting array of causal mechanisms, some of which are themselves quite specific to a given time and place.

\section{References}

Abbott, A. (2005). The idea of outcome in U.S. sociology. In G. Steinmetz (Ed.), The politics of method in the human sciences: Positivism and its epistemological others (pp. 393-426). Durham, NC: Duke University Press.

Adams, J., Clemens, E. S., \& Orloff, A. S. (2005). Introduction: social theory, modernity, and the three waves of historical sociology. In J. Adams, E. S. Clemens \& A. S. Orloff (Eds.), Remaking modernity: Politics, history, and sociology (pp. 1-72). Durham: Duke University Press.

Adorno, T. (1968). Scientific experiences of a European scholar in America. Perspectives in American History, 2, 338-370.

Adorno, T. (1972). Zur gegenwärtigen Stellung der empirischen Sozialforschung in Deutschland (1951/52). In T. Adorno (Ed.), Gesammelte Schriften, vol. 8 (pp. 478-493). Frankfurt am Main: Suhrkamp.

Albert, H. (1956). Entmythologisierung der Sozialwissenschaften. Die Bedeutung der analytischen Soziologie für die soziologische Erkenntnis. Kölner Zeitschrift für Soziologie und Sozialpsychologie, 8 (2), 243-271.

Anderson, N. (1923). The Hobo; The sociology of the homeless man. Chicago: University of Chicago Press.

Anderson, N. (1956). Die Darmstadt-Studie. Ein informeller Rückblick. In König René (Ed.), Soziologie der Gemeinde, special issue Kölner Zeitschrift für Soziologie und Sozialpsychologie Sonderheft 1 (pp. 144171). Cologne: Westdeutscher.

Aron, R. (1935). La sociologie allemande contemporaine. Paris: Alcan.

Averbeck, S. (1999). Ernst Manheims wissenschaftliches Jahrhundert: Erkenntnistheorie und Empirie. Newsletter-Archiv für die Geschichte der Soziologie in Österreich, 19, 1-20. 
Averbeck, S. (2005). Ernst Manheim's Träger der öffentlichen Meinung: Eine Theorie der Öffentlichkeit 30 Jahre vor Jurgen Habermas. In F. Baron, et al. (Eds.), Authority, culture, and communication: The sociology of Ernest Manheim (pp. 43-70). Heidelberg: Synchron.

Bahr, E. (2007). Weimar on the Pacific: German exile culture in Los Angeles and the crisis of modernism. Berkeley: University of California Press.

Barnes, H. E., \& Becker, H. (1938). Social thought from lore to science (vol. 1). Boston: Heath.

Barth, F., Gingrich, A., Parkin, R., \& Silverman, S. (2005). One discipline, four ways: British, German, French, and American Anthropology. Chicago: University of Chicago Press.

Becker, C. H. (1925). Vom Wesen der deutschen Universität. Leipzig: Quelle \& Meyer.

Becker, H. P. (1930). Ionia and Athens. Studies in Secularization. Ph.D. dissertation, University of Chicago.

Becker, H. P. (1934). Historical Sociology. In L. L. Bernard (Ed.), The fields and methods of sociology (pp. 18-34). New York: Long and Smith.

Bendix, R. (1943). The Rise and Acceptance of German Sociology. Unpublished MA thesis, University of Chicago.

Bensman, J., Vidich, A. J., \& Gerth, N. (eds). (1982). Politics, character, and culture: Perspectives from Hans Gerth. Westport, CT: Greenwood.

Bernard, L. L. (1909). The Teaching of Sociology in the United States. The American Journal of Sociology, Vol. 15, No. 2 (Oct., 1909), pp. 164-213.

Bleek, W. (2001). Geschichte der Politikwissenschaft in Deutschland. München: Beck.

Blomert, R. (1999). Intellektuelle im Aufbruch: Karl Mannheim, Alfred Weber, Norbert Elias und die Heidelberger Sozialwissenschaften der Zwischenkriegszeit. München: Hanser.

Bock, M. (1994). Entwicklung der Soziologie und die Krise der Geisteswissenschaften in den 20er Jahren. In K. W. Nörr (Ed.), Geisteswissenschaften zwischen Kaiserreich und Republik (pp. 159-185). Stuttgart: Steiner.

Bourdieu, P. (1991). The political ontology of Martin Heidegger. Oxford: Polity.

Bourdieu, P. (2000). Propos sur le champ politique. Lyon: Presses Universitaires de Lyon.

Bourdieu, P., \& Wacquant, L. (2000). The organic ethnologist of Algerian Migration. Ethnolography, 1, $173-182$.

Brecht, B. (1998 [1940]). Flüchtlingsgespräche. In W. Hecht, et al. (Eds.), Bertolt Brecht. Werke (Vol. 18) (pp. 195-327). Berlin: Aufbau.

Cahnman, W. J. (1943). The Mediterranean and Caribbean Regions - a comparison in race and culture contacts. Social Forces, 22, 209-214.

Cahnman, W. J. (1960). Review of From history to sociology: The transition in German historical thinking, by Carlo Antoni. American Sociological Review, 25, 120-121.

Cahnman, W. J. (1966). The historical sociology of cities: a critical review. Social Forces, 45, 155-161.

Cahnmann, W. J. (1978). Historische Soziologie: Was sie ist und was nicht. Die deutsche UniversitätsZeitung vereinigt mit Hochschul-Dienst, 15, 458-462.

Cahnman, W. J. (1989). German Jewry: Its history and sociology: Selected essays by Werner J. Cahnman. Brunswick, NJ: Transaction Books.

Cahnman, W. J., \& Boskoff, A. (1964). Sociology and history: Review and outlook. In W. J. Cahnman \& A. Boskoff (Eds.), Sociology and history: Theory and research (pp. 560-580). New York: Free Press of Glencoe.

Calhoun, C. (ed). (2007). Sociology in America. A history. Chicago: University of Chicago Press.

Calhoun, C., \& VanAntwerpen, J. (2007). Orthodoxy, heterodoxy, and hierarchy: "Mainstream" sociology and its challenges. In C. Calhoun (Ed.), Sociology in America. A history (pp. 367-410). Chicago: University of Chicago Press.

Calhoun, C. (1996). The rise and domestication of historical sociology. In T. J. McDonald (Ed.), The historic turn in the human sciences (pp. 305-338). Ann Arbor: University of Michigan Press.

Cohen, G. A. (2001). Karl Marx's theory of history: A defence. Princeton, NJ: Princeton University Press.

Comhaire, J., \& Cahnman, W. J. (1962). How cities grew: The historical sociology of cities. Madison, NJ: Florham Park

Coser, L. (1984). Refugee scholars in America. Their impact and their experiences. New Haven: Yale University Press.

Derks, H. (2001). Review of Soziologie im Dritten Reich, by Carsten Klingemann. The European Legacy, 6 , $491-499$.

Diesener, G. (1993). Karl Lamprecht weiterdenken: Universal- und Kulturgeschichte heute. Leipzig: Leipziger Universitätsverlag.

Ermakoff, I. (2008). Ruling oneself out: A theory of collective abdications. Durham, NC: Duke University Press.

Etzkorn, K. P. (1987). Paul Honigsheims wissenschaftlichen Wirkungen in den Vereinigten Staaten. In A. Silbermann and P. Röhrig (Eds.), Kultur, Volksbildung und Gesellschaft. Paul Honigsheim zum Gedenken seines 100. Geburtstages (pp. 51-66). Frankfurt am Main: Peter Lang. 
Faulenbach, B. (1982). Eugen Rosenstock-Huessy. In H.-U. Wehler (Ed.), Deutsche Historiker, vol. 9 (pp. 102-126). Göttingen: Vandenhoeck \& Ruprecht.

Fleck, C. (2007). Transatlantische Bereicherungen. Zur Erfindung der empirischen Sozialforschung. Frankfurt: Suhrkamp.

Fourcade, M. (2009). Economists and societies: Discipline and profession in the United States, Britain, and France, 1890s to 1990s. Princeton: Princeton University Press.

Francis, E. (1951). History and the social sciences: Some reflections on the re-integration of social science. The Review of Politics, 13, 354-374.

Francis, E. (1965). Ethnos und Demos. Soziologische Beiträge zur Volkstheorie. Berlin: Duncker \& Humblot.

Franzis, E. (1933). Bernard Bolzano, der pädagogische Gehalt seiner Lehre. Münster in Westfalen: Aschendorff.

Freyer, H. (1926). Soziologie als Geisteswissenschaft. Archiv für Kulturgeschichte, 26, 113-126.

Freyer, H. (1930). Soziologie als Wirklichkeitswissenschaft;logische Grundlegung des Systems der Soziologie. Leipzig: Teubner.

Freyer, H. (1931). Revolution von rechts. Jena: Diederichs.

Freyer, H. (1933). Herrschaft und Planung. Hamburg: Hanseatische Verlagsanstalt.

Freyer, H. (1954). Weltgeschichte Europas. Stuttgart: Deutsche Verlags-Anstalt.

Frisby, D. (1986). Fragments of modernity: Theories of modernity in the work of Simmel, Kracauer, and Benjamin. Cambridge, MA: MIT.

Gemelli, G. (2000). Permanent connections: Paul Lazarsfeld, American Foundations and Europe (1930s1960s). In G. Gemelli (Ed.), The "Unacceptables": American Foundations and refugee scholars between the two wars and after (pp. 241-272). Brussels: Peter Lang.

Gerhardt, U. (2007). Denken der Demokratie. Die Soziologie im atlantischen Transfer des Besatzungsregimes. Stuttgart: Franz Steiner.

Gerth, H. (1959). The relevance of history to the sociological ethos. Studies on the Left, 1, 7-14.

Gerth, H. (1976). Bürgerliche Intelligenz um 1800: zur Soziologie des deutschen Frühliberalismus. Göttingen: Vandenhoeck und Ruprecht.

Gerth, N. (2002). "Between two worlds": Hans Gerth. Jahrbuc h für Soziologiegeschichte 1999/2000. Opladen: Leske + Budrich.

Glatzer, W. (1994). Deutsche Gesellschaft für Soziologie. Soziologie, 3, 216-231. special edition.

Grathoff, R. (1974). Biographisches. In A. Brecht, P. Berger \& R. Grathoff (Eds.), Carl Mayer 1902/1974 (pp. 9-16). Konstanz: Verlagsanstalt Konstanz.

Grünfeld, E. (1913). Hafenkolonien und Kolonieähnliche Verhältnisse in China, Japan und Korea; eine kolonialpolitische Studie. Jena: Fischer.

Grünfeld, E. (1939). Die Peripheren: ein Kapitel Soziologie. Amsterdam: N. v. Noord-hollandsche uitgevers mij.

Grüttner, M., \& Kinas, S. (2007). Die Vertreibung von Wissenschaftlern aus den deutschen Universitäten 1933-1945. Vierteljahrshefte für Zeitgeschichte, 55, 123-186.

Gugolz, A. (1984). Charisma und Rationalität in der Gesellschaft: die Religionssoziologie Carl Mayers zwischen klassischen Theorien und moderner Wissenssoziologie. Berlin: Duncker \& Humblot.

Hagemann, H., \& Krohn, C.-D. (eds). (1999). Biographisches Handbuch der deutschsprachigen wirtschaftswissenschaftlichen Emigration nach 1933. München: Saur.

Hardin, B. (1977). The professionalization of sociology. A comparative study: Germany-USA. Frankfurt: Campus.

Heilbron, J. (2008). Qu'est-ce qu'une tradition nationale en sciences sociales? Revue d'Histoire des Sciences Humaines, 18, 3-16.

Heilbron, J., Guilhot, N., \& Jeanpierre, L. (2008). Toward a transnational history of the social sciences. Journal of the History of the Behavioral Sciences, 44, 146-160.

Henning, C. (2006). 'Der übernationale Gedanke der geistigen Einheit'. Gottfried Salomon (-Delatour), der vergessene Soziologe der Verständigung. In A. Barboza \& C. Henning (Eds.), Deutsch-jüdische Wissenschaftsschicksale: Studien über Identitätskonstruktionen in der Sozialwissenschaft (pp. 48-100). Bielefeld: Transcript.

Herman, E. (1996). The romance of American psychology: Political culture in the age of experts. Berkeley, CA: University of California Press.

Hinkle, R. C., Jr., \& Hinke, G. (1954). The development of modern sociology, its nature and growth in the United States. New York: Random.

Holzner, B. (1965). Review of Sociology and History: Theory and Research, eds. Werner J. Cahnman and Alvin Boskoff. Social Forces, 43, 579-580.

Jay, M. (1975-1976). The extraterritorial life of Siegfried Kracauer. Salmagundi, 31-32, 49-106.

Kaesler, D., \& Vogt, L. (eds). (2000). Hauptwerke der Soziologie. Stuttgart: Kröner. 
Kaesler, D. (1984). Die frühe deutsche Soziologie 1900 bis 1934 und ihre Entstehungs-Milieus. Opladen: Westdeutscher.

Karger, U. (1978). Institutionsgeschichtliche Zäsuren in der deutschen Soziologie. Dargestellt am Beispiel der Deutschen Soziologentage. Dissertation, Ruhr-Universität Bochum.

Kiser, E., \& Hechter, M. (1991). The role of general theory in comparative-historical sociology. American Journal of Sociology, 97, 1-30.

Klingemann, C. (1986). Soziologie an Hochschulen im NS-Staat (2). Zeitschrift für Hochschuldidaktik, 10, 127155.

Klingemann, C. (1988). Erinnerungen an das Seminar für Soziologie zwischen 1939 und 1945. In R. Wassner \& M. Berghaus (Eds.), Wege zum Sozialen: 90 Jahre Soziologie in Hamburg (pp. 85-97). Opladen: Leske + Budric.

Klingemann, C. (1992). Social-scientific experts-no ideologues. Sociology and social research in the Third Reich. In P. Turner \& D. Käsler (Eds.), Sociology responds to fascism (pp. 127-154). London: Sage.

Klingemann, C. (1996). Soziologie im Dritten Reich. Baden-Baden: Nomos Verlagsgesellschaft.

König, R. (1958). Soziologie. Frankfurt am Main: Fischer.

Köttgen, A. (1933). Deutsches Universitätsrecht. Tübingen: Mohr.

Kracauer, S. (1922). Soziologie als Wissenschaft: Eine erkenntnistheoretische Untersuchung. Dresden: Sibyllen.

Kracauer, S. (1952-1953). The challenge of qualitative content analysis. The Public Opinion Quarterly, 16, 631-642.

Kracauer, S. (1995 [1969]). History: The last things before the last. Princeton: Wiener.

Kracauer, S. (1998 [1930]). The salaried masses: Duty and distraction in Weimar Germany. London: Verso.

Krohn, C. D. (1993 [1987]). Intellectuals in exile: Refugee scholars and the new school for social research. Amherst: University of Massachusetts Press.

Krohn, C.-D. (2000). American Foundations and Refugee scholars between the Two Wars. In G. Gemelli (Ed.), The "Unacceptables": American Foundations and Refugee Scholars between the Two Wars and After (pp. 35-50). Brussels: P.I.E.-Peter Lang. Wiese, 1948.

Kruse, V. (1999a). Analysen zur deutschen historischen Soziologie. Münster: LIT.

Kruse, V. (1999b). 'Geschichts- und Sozialphilosophie' oder Wirklichkeitswissenschaft? Frankfurt am Main: Suhrkamp.

Kruse, V. (2001). Wozu Soziologiegeschichte? Das Beispiel der deutschen historischen Soziologie. Jahrbuch für Soziologiegeschichte, 1997(1998), 105-114.

Lamberti, M. (2006). The reception of refugee scholars from Nazi Germany in America: philanthropy and social change in higher education. Jewish Social Studies, 12, 157-192.

Lamont, M. (2009). How professors think. Cambridge: Harvard University Press.

Landshut, S. (1929). Kritik der Soziologie. München: Duncker \& Humblot.

Lazarsfeld, P. (1969). An episode in the history of social research: A memoir. In D. Fleming (Ed.), The intellectual migration. Europe and America, 1930-1960 (pp. 270-337). Cambridge, MA: Harvard University Press.

Lepsius, M. R. (1983). The development of sociology in Germany after World War II (1945-1968). International Journal of Sociology, 13, 3-88.

Lukács, G. (1981). The destruction of reason. Atlantic Highlands, NJ: Humanities.

Lüschen, G. (1994). 25 Years of German sociology after World War II: Institutionalization and theory. Soziologie, 3, 11-32. special edition.

Mahoney, J., \& Rueschemeyer, D. (2003). Comparative-historical analysis: achievements and agendas. In J. Mahoney \& D. Rueschemeyer (Eds.), Comparative-historical analysis in the social sciences (pp. 3-38). New York: Cambridge University Press.

Maier, J. B., \& Waxman, C. I. (1983). Ethnicity, identity, and history: Essays in memory of Werner J. Cahnman. New Brunswick, NJ: Transaction Books.

Manheim, E. (1979 [1933]). Aufklärung und öffentliche Meinung: Studien zur Soziologie der Öffentlichkeit im 18. Jahrhundert. Stuttgart: Frommann-Holzboog.

Mannheim, K. (1932a). Die Gegenwartsaufgaben der Soziologie: ihre Lehrgestalt. Tübingen: Mohr.

Mannheim, K. (1932b). Review of Methods in Social Science, by Stuart A. Rice. American Journal of Sociology, 38, 273-282.

Mannheim, K. (1952 [1924]). Historicism. In P. Kecskemeti (Ed.), Karl Mannheim, Essays on the Sociology of Knowledge (p. 84). London: Routledge and Kegan Paul.

Maus, H. (1962). A short history of sociology. New York: Philosophical Library.

Mayer, C. (1935). Max Weber's interpretation of Karl Marx. Social Research, 42, 701-719.

Mennell, S. (1992). Norbert Elias. An introduction. Oxford: Blackwell. 
Meyer, J. (1928). Die Entstehung des Patriziats in Nürnberg (Mitteilungen des Vereins für die Geschichte der Stadt Nürnberg, vol. 27). Nürnberg: Schrag.

Michel, U. (1992). Wilhelm Emil Mühlmann (1904-1988) - ein deutscher Professor. Amnesie und Amnestie: Zum Verhältnis von Ethnologie und Politik im Nationalsozialsmus. Jahrbuch für Soziologiegeshichte, 1991, 69-117.

Mierendorff, M. (1959). Kracauer, Siegfried. In W. Bernsdorf (Ed.), Internationales Soziologen Lexikon (p. 280). Stuttgart: Enke.

Mihic, S., Engelmann, S. G., \& Wingrove, E. R. (2005). Facts, values, and 'real' numbers. In G. Steinmetz (Ed.), The politics of method in the human sciences: Positivism and its epistemological others (pp. 470495). Durham, NC: Duke University Press.

Mills, C. W. (1959). The sociological imagination. Oxford: Oxford University Press.

Mühlmann, W. E. (1932). Die geheime gesellschaft der Arior. Leiden: Brill.

Muller, J. Z. (1987). The other God that failed: Hans Freyer and the deradicalization of German conservatism. Princeton, NJ: Princeton University Press.

Murphy, M. (2005). ASA's history in a 'nutshell'. ASA Footnotes, March, 5.

Nicolaysen, R. (1997). Siegfried Landshut: die Wiederentdeckung der Politik. Frankfurt am Main: Jüdischer.

Oakes, G. (1987). Weber and the Southwest German School: The genesis of the concept of the historical individual. In T. Mommsen \& J. Osterhammel (Eds.), Max Weber and his contemporaries (pp. 434446). London: Unwin Hyman.

Oppenheimer, F. (1964). Erlebtes, erstrebtes, erreichtes: Lebenserinnerungen. Düsseldorf: Melzer.

Park, R. E., \& Burgess, E. W. (1924). Introduction to the science of sociology. Chicago: University of Chicago Press.

Plé, B. (2001). 'Social Sciences' in der Ordnungspolitik der USA: vom Kriegseinsatz zum Medium amerikanischer Kulturpolitik im Nachkriegsdeutschland, 1941-1957. Jahrbuch für Soziologiegeschichte, 1997-1998, 195-214.

Pollak, M. (1979). Paul F. Lazarsfeld, fondateur d'une multinationale scientifique. Actes de la recherche en sciences sociales, $25,45-59$.

Raith, D. (1999). Lebenserfahrung und historische Distanz. Nina Rubinstein (1908-1996) und ihr Beitrag zur Soziologie der politischen Emigration. Archiv für die Geschichte der Soziologie in Österreich, 19, 32 41.

Remy, S. P. (2002). The Heidelberg myth: The nazification and denazification of a German University. Cambridge, MA: Harvard University Press.

Revel, J., \& Wachtel, N. (1996). Une école pour les sciences sociales: de la VIe section à l'École des hautes études en sciences socials. Paris: Les Editions du Cerf.

Röhrig, P. (1987). Paul Honigsheim und die Volksbildung. In A. Silbermann and P. Röhrig (Eds.), Kultur, Volksbildung und Gesellschaft. Paul Honigsheim zum Gedenken seines 100. Geburtstages (pp. 101-120). Frankfurt am Main: Peter Lang.

Ross, D. (1991). The origins of American social science. Cambridge: Cambridge University Press.

Roth, G. (1963). The social democrats in imperial Germany; a study in working-class isolation and national integration. Totowa, NJ: Bedminster.

Rubinstein, N. (2000). Die französische Emigration nach 1789: ein Beitrag zur Soziologie der politischen Emigration. Graz: Nausner \& Nausner.

Rule, J. B. (2003). Lewis Coser: 1913-2003. Dissent, 50, 93-94.

Rutkoff, P. M., \& Scott, W. B. (1986). New school: A history of the new school for social research. New York: Free.

Said, E. W. (2000). Reflections on exile. In E. W. Said (Ed.), Reflections on exile and other essays (pp. 173186). Cambridge, MA: Harvard University Press.

Salomon, G. (1922). Das Mittelalter als Ideal in der Romantik. München: Drei Masken.

Salomon, A. (1935). Max Weber's methodology. Social Research, 1, 147-163.

Sayad, A. (1999). La double absence: Des illusions de l'émigré aux souffrances de l'immigré. Paris: Seuil.

Schäfer, G. (1990). Wider die Inszenierung des Vergessens: Hans Freyer und die Soziologie in Leipzig 19251945. Jahrbuch für Soziologie, 1990, 121-177.

Scheler, M. (1926). Die Wissensformen und die Gesellschaft. Leipzig: der Neue-geist.

Schelsky, H. (1959). Ortsbestimmung der deutschen Soziologie. Düsseldorf: Diederich.

Schelsky, H. (1961). Der Mensch in der wissenschaftlichen Zivilisation. Köln: Westdeutscher.

Scheuch, E. (1990). Von der deutschen Soziologie zur Soziologie in der Bundesrepublik Deutschland. Österreichische Zeitschrift für Soziologie, 15, 30-50.

Schweber, L. (2006). Disciplining statistics: Demography and vital statistics in France and England, 18301885. Durham: Duke University Press. 
Sewell, W. H. (1996). Three temporalities: Toward an eventful sociology. In T. J. McDonald (Ed.), The historic turn in the human sciences (pp. 245-280). Ann Arbor: University of Michigan Press.

Sewell, W. H. (2005). The political unconscious of social and cultural history, or, confessions of a former positivist historian. In W. H. Sewell Jr. (Ed.), Logics of history: Social theory and social transformation (pp. 22-80). Chicago: University of Chicago Press.

Siefer, G., \& Abrahams, F. (1994). Studying sociology in postwar Germany: A historical synopsis of the development of academic learning programs at German Institutions of Higher Learning. Soziologie, 3, 284-297. special edition.

Sigrist, C., \& Kößler, R. (1985). Soziologie in Heidelberg. In K. Buselmeier, D. Harth \& C. Jansen (Eds.), Auch eine Geschichte der Universität Heidelberg (pp. 79-99). Mannheim: Edition Quadrat.

Silbermann, A., \& Röhrig, P. (eds). (1987). Kultur, Volksbildung und Gesellschaft. Paul Honigsheim zum Gedenken seines 100. Geburtstages. Frankfurt am Main: Peter Lang.

Small, A. (1905). General sociology. Chicago: University of Chicago Press.

Smith, D. N. (2005). Facing change and danger. The sociology of Ernest Manheim. In F. Baron, et al. (Eds.), Authority, culture, and communication: The sociology of Ernest Manheim (pp. 3-23). Heidelberg: Synchron.

Speier, H. (1986). German white-collar workers and the rise of Hitler. New Haven, CT: Yale University Press.

Speier, H. (1989). The truth in hell and other essays on politics and culture, 1935-1987. New York: Oxford University Press.

Spohn, W. (1996). Zur Programmatik und Entwicklung der neuen historischen Soziologie. Berliner Journal für Soziologie, 3, 363-374.

Steinert, H. (1990). Die fünfte Fakultät: Strömungen in der Geschichte der Sozialwissenschaften an der Universität Frankfurt. In H. Steinert (Ed.), Die (mindestens) zwei Sozialwissenschaften in Frankfurt und ihre Geschichte. Frankfurt am Main: J.W. Goethe-Universität.

Steinmetz, G. (1997). German exceptionalism and the origins of Nazism: The career of a concept. In I. Kershaw \& M. Lewin (Eds.), Stalinism and nazism: Dictatorships in comparison (pp. 251-284). Cambridge: Cambridge University Press.

Steinmetz, G. (1999). Culture and the State. In G. Steinmetz (Ed.), State/culture. Historical studies of the state in the social sciences (pp. 1-49). Ithaca, NY: Cornell University Press.

Steinmetz, G. (2004). Odious comparisons: Incommensurability, the case study, and "small N's in sociology". Sociological Theory, 22, 371-400.

Steinmetz, G. (2005a). American sociology's epistemological unconscious and the transition to post-fordism: the case of historical sociology. In J. Adams, et al. (Eds.), Remaking modernity: Politics, processes and history in sociology (pp. 109-157). Durham, NC: Duke University Press.

Steinmetz, G. (2005b). Scientific authority and the transition to post-fordism: The plausibility of positivism in American sociology since 1945. In G. Steinmetz (Ed.), The politics of method in the human sciences: Positivism and its epistemological others (pp. 275-323). Durham, NC: Duke University Press.

Steinmetz, G. (2005c). Introduction. In G. Steinmetz (Ed.), The politics of method in the human sciences: Positivism and its epistemological others (pp. 1-56). Durham, NC: Duke University Press.

Steinmetz, G. (2007a). American Sociology before and after World War Two: The (temporary) settling of a disciplinary field. In C. Calhoun (Ed.), Sociology in America. A history (pp. 258-293). Chicago: University of Chicago Press.

Steinmetz, G. (2007b). Fordism and the positivist revenant: Response to Burris, Fourcade-Gourinchas, and Riley. Social Science History, 31, 127-152.

Steinmetz, G. (2007c). Transdisciplinarity as a nonimperial encounter: For an open sociology. Thesis Eleven, $92,48-65$.

Stendenbach, F. J. (1964). Sociology in Germany since 1945. Social Science Information, 3, 7-51.

Stölting, E. (1984). Kontinuitäten und Brüche in der deutschen Soziologie 1933/34. Soziale Welt, 35, 48-59.

Strauss, H. A., \& Röder, W. (eds). (1983). International biographical dictionary of central European Émigrés 1933-1945, Vol. II. München: Saur.

Sutherland, D. E. (1974). On the migration of sociological structures, 1933-1941: A forgotten episode in the history of American sociology and a case study in the sociology of sociology. Current Sociology, 22, $87-121$.

Szöllösi-Janze, M. (2001). National socialism and the sciences: Reflections, conclusions, and historical perspectives. In M. Szöllösi-Janze (Ed.), Science in the third Reich (pp. 1-36). Oxford: Berg.

Troeltsch, E. (1924). Der Historismus und seine Überwindung; fünf Vorträge. Berlin: Heise.

Üner, E. (1994). Soziologie als Wirklichkeitswissenschaft. Wirtschaft und Wissenschaft, 2, 7-12.

von Below, G. (1926). Zum Streit um das Wesen der Soziologie. Jahrbücher für Nationalökonomie und Statistik, 124, 218-242. 
von Borch, H. (1955). Grundlagen der Geschichtssoziologie. In A. Weber, et al. (Eds.), Einführung in die Soziologie (pp. 171-205). München: Piper.

von Ferber, C. (1956). Die Entwicklung des Lehrkörpers der deutschen Universitäten und Hochschulen 1864-1954. Göttingen: Vanderhoeck \& Ruprecht.

von Martin, A. (1948). Geist und Gesellschaft: Soziologische Skizzen zur europäischen Kulturgeschichte. Frankfurt am Main: Knecht.

von Martin, A. (1951). Die bürgerlich-kapitalistische Dynamik der Neuzeit seit der Renaissance. Historische Zeitschrift, 172, 37-64.

von Wiese, L. (1948). Erster Vortrag. Die gegenwärtige Situation, soziologisch Betrachtet. In Verhandlungen des Achten Deutschen Soziologentages (pp. 20-41). Tübingen: Verlag J.C.B. Mohr.

Wagner, P., et al. (eds). (1999). Social sciences and modern states: National experiences and theoretical crossroads. Cambridge: Cambridge University Press.

Walther, A. (1927). Soziologie und Sozialwissenschaften in Amerika. Karlsruhe: Braun.

Wassner, R. (1985). Andreas Walther und die Soziologie in Hamburg. Dokumente, Materialien, Reflexionen. Hamburg: Institut für Soziologie der Universität Hamburg.

Wassner, R. (1986). Andreas Walther und das Seminar für Soziologie in Hamburg zwischen 1926 und 1945. Ein wissenschaftsbiographischer Umriss. In S. Papcke (Ed.), Ordnung und Theorie: Beiträge zur Geschichte der Soziologie in Deutschland (pp. 396-420). Darmstadt: Wissenschaftliche Buchgesellschaft.

Weber, A. (1921). Prinzipelles zur Kultursoziologie. Archiv für Sozialwissenschaften und Sozialpolitik, 47, $1-49$.

Weber, A. (1927). Ideen zur Staats- und Kultursoziologie. Karlsruhe: Braun.

Weber, A. (1931). Kultursoziologie. In A. Vierkandt (Ed.), Handwörterbuch der Soziologie (pp. 284-294). Stuttgart: Ferdinant Enke.

Weber, A. (1935). Kulturgeschichte als Kultursoziologie. Leiden: Sijthoff's uitgeversmaatschappij.

Weber, M. (1946). Science as a vocation. In H. Gerth \& C. W. Mills (Eds.), From Max Weber: Essays in sociology (pp. 129-158). New York: Oxford University Press.

Weyer, J. (1984). Westdeutsche Soziologie 1945-1960. Berlin: Duncker \& Humblot.

Wiggershaus, R. (1994). The Frankfurt School: Its history, theories, and political significance. Cambridge: Polity.

Witte, K. (1987). Siegfried Kracauer in Exil. Exilforschung, 5, 135-149.

Wittebur, K. (1991). Die deutsche Soziologie im Exil 1933-1945: Eine biographische Karthographie. Münster: Lit. 